\title{
Service-Learning and Graduation: Evidence from Event History Analysis
}

\author{
Hongtao Yue and Steven M. Hart \\ California State University, Fresno
}

\begin{abstract}
This research employed Event History Analysis to understand how service-learning participation is related to students' graduation within six years. The longitudinal dataset includes 31,074 new undergraduate students who enrolled in a large western U.S. public university from Fall 2002 to Fall 2009. The study revealed that service-learning participation had a significant positive relationship with graduation for both first-time freshmen and new undergraduate transfers. Furthermore, participation in upper division service-learning courses had larger correlations with graduation than participating in lower division service-learning courses, and service-learning participation had larger correlations with graduation for new undergraduate transfers than for first-time freshmen.
\end{abstract}

The lower rate of graduation with a baccalaureate degree and increased time to degree completion have caught the attention of policy makers, educators, and researchers in recent years. Many states and higher education institutions have implemented intervention programs to promote timely graduation. Service-learning (SL) has been recognized as a high-impact practice (HIP) (Brownell \& Swaner, 2010; Kuh, 2008) but there are few studies on the long-term effects of SL on graduation. This study applies Event History Analysis (EHA) on longitudinal data to understand service-learning's longterm relationship with graduation.

\section{Graduation and Time to Degree}

Nationally, among first-time, full-time undergraduate students who began their pursuit of a bachelor's degree at a 4-year degree-granting institution in Fall 2007, 39.4\% graduated within four years, $55.1 \%$ graduated within five years, and $59.4 \%$ graduated within six years. The 4-, 5-, and 6-year graduation rates are even lower for all 4year public institutions at 33.5\%, 52.3\% and 57.7\% respectively (Kena et al., 2015). In addition, time to graduation with a baccalaureate degree has increased markedly in the United States (Bound, Lovenheim, \& Turner, 2012). The median time to earn a Bachelor's degree from public institutions in 2008 was 55 months for all degree recipients, 63 months for graduates who started at a 2-year public institution, and 80 months for those who delayed entry into postsecondary education (Cataldi et al., 2011).
Many states have implemented performancebased funding initiatives to encourage higher educational institutions to improve graduation and shorten time to degree. By June 2015, 32 states had a funding formula or policy in place to allocate a portion of funding based on performance indicators, and five other states are currently transitioning to some type of performance funding (National Conference of State Legislatures, 2015). More and more higher education institutions have implemented graduation initiatives. For example, in 2007, the presidents and chancellors of nearly two dozen public postsecondary systems created the Access to Success Initiative to increase the number of college-educated adults, and to graduate more young people from low-income and minority families (Engle \& Lynch, 2009). The most common component among these initiatives is to identify HIPs and integrate them into intervention strategies.

\section{Theoretical Framework}

Several theoretical models have been developed to explain the multiple influences on students' successful degree completion. The current study was guided by the intersection of integration (Tinto, 1993), involvement (Astin, 1999), and engagement (Kuh, Kinzie, Schuh, Whitt, \& Associates, 2005) models. Although each of these models provides a unique lens to analyzing issues of persistence and graduation, they share a focus on three main factors: individual (e.g., family background, attitudes, goals); institutional (e.g., size, programs, struc- 
tures); and student-institution interactions (e.g., social integration, academic engagement).

These models acknowledge the important roles students' individual characteristics and previous life experiences hold as they enter into and interact within higher education contexts. Though a robust body of research has found that particular individual student characteristics, such as gender, race and ethnicity, economic status, and academic preparedness correlate with persistence and degree completion (Astin \& Oseguera, 2005; Crisp \& Nora, 2010; DeAngelo, Franke, Hurtado, Pryor, \& Tran, 2011; Pike, Hansen, \& Childress, 2014), these characteristics are not necessarily inevitable determinants of which students can succeed. Recent studies have shown that many institutions have demonstrated progress in increasing graduation rates for many students represented by these traits (Nguyen, Bibo, \& Engle, 2012a; Nguyen, Bibo, \& Engle, 2012b; Lynch \& Engle, 2010a; Lynch \& Engle, 2010b). Such findings support the notion that what happens at institutions matters. In the next section, we review the models framing this study to elaborate on the student-institution interaction components.

\section{Integration and Involvement Models}

Tinto's (1993) theory of college student departure is the most widely cited theory of college student persistence and degree completion. Based on the notion that dropping out from higher education represents a form of social withdrawal, this model asserts that integration is crucial to the process of student adaptation to the college culture. That is, integration is a process of developing a sense of belonging and coming to share the institution's values. This integration theory posits that students enter higher education with an initial level of commitment to their goals and the cultural values of their institutions. Students' levels of commitment determine their degree of integration into, or acceptance of, the academic and social value systems of their respective campuses. In turn, students' levels of integration into the academic and social contexts of their campuses shape their subsequent commitments to their goals and their institution. These commitments, in turn, determine students' likelihood of success.

Whereas Tinto's (1993) integration model emphasizes the internal sense of belonging by adapting to the university culture, Astin (1999) offered the concept of college student involvement to focus on students' behaviors. Astin posited that the quality and quantity of students' involvement - their activities - in college are important factors in predict- ing educational outcomes. According to this theory, college students' involvement is associated with higher levels of satisfaction with the college experience, persistence, and completion. Specifically, this theory of involvement suggests that experiences in college, such as interaction with faculty members and membership in student groups, are associated with learning and success outcomes. Like Tinto's integration model, the involvement model emphasizes how a student develops a sense of belonging to the institution.

\section{Engagement Theory}

In line with Astin's (1999) involvement theory, the concept of student engagement highlights the impact of students' experiences in college on their learning and success outcomes. Similarly, this model emphasizes the role of the institution in implementing practices that promote student engagement. Most often associated with the work of Kuh and his colleagues (Kuh et al., 2005), this model of engagement suggests that it is high-impact practices that promote students' participation in educationally purposeful activities and enhances students' levels of learning and likelihood of success in college. According to Kuh (2008), high-impact practices are effective because they provide opportunities for students to experience and take part in the intellectual culture of the college or university.

\section{Service-learning as \\ High Impact Practice (HIP)}

Service-learning (SL) is recognized as one HIP (Brownell \& Swaner, 2010; Kuh, 2008) and has become a popular pedagogical approach for enhancing student learning (Chupp \& Joseph, 2010). SL is a pedagogy in which students learn by active participation in organized services that address community issues and is linked to academic study through structured reflection. Compared to other experiential learning approaches such as field work and internships, SL is unique in that it combines meaningful community service with related academic content, ties the two with critical analysis, and focuses on civic learning outcomes (Furco, 1996).

Numerous studies conducted over the last two decades have documented the positive impacts of SL on students' personal development (Bringle, Clayton, \& Hatcher, 2013; Celio, Durlak, \& Dymnicki, 2011; Eyler \& Giles, 1999; Yorio \& Ye, 2012), social development (Astin \& Sax, 1998; Celio et al; Eyler, 2000; Jacoby, 2009; Yorio \& Ye), and academic learning (Bringle et al.; Celio et al.; 
Eyler, Giles, Stenson, \& Gray, 2001; Novak, Markey, \& Allen, 2007; Warren, 2012; Yorio \& Ye).

Researchers also have found that the positive impacts of SL on students may be moderated by certain factors (Aronson et al., 2005; Roldan, Strage, \& David, 2004; Whitley, 2014). These factors are related to SL courses, faculty, or students, including course discipline; the level of the course; the type of course (e.g., general education vs. non-general education, major requirement vs. elective); the size of the SL courses; the degree the SL experience is integrated into the course learning objectives; students' demographics (e.g., socioeconomic status, gender, race and ethnicity, first-generation status); and students' academic abilities (e.g., higher GPA).

However, there is limited understanding of the relationships between SL and long-term outcomes such as persistence, graduation, and postgraduation employment. A few studies found a positive relationship between SL participation and students' persistence in school (Bringle, Hatcher, \& Muthiah, 2010; Gallini \& Moely, 2003). Matthews, Dorfman, and $\mathrm{Wu}$ (2015) found significantly higher starting salaries and shorter time to receive a first raise for graduates with SL experience. There is only one published study examining the relationship between SL and graduation (Lockeman \& Pelco, 2013), which found that students who participated in SL courses during their undergraduate years were more likely to earn a baccalaureate degree than students who did not participate in SL coursework.

\section{Research Design}

We have limited studies linking SL and graduation primarily because of two barriers: data availability and research method. It is difficult for researchers to track students' SL participation and progression toward graduation, and there is no agreed-upon method to model the effects of SL on graduation as a longitudinal process. In this study, we examined SL participation and graduation across terms and attempt to overcome both barriers.

Particularly, this study employed large-scale longitudinal data and applied EHA to answer the following three questions: (a) Is SL participation associated with students' graduation within six years?, (b) If so, are there any differential effects of SL participation among different SL courses (lower vs. upper division) or among different student populations (first-time freshmen vs. new undergraduate transfers)?, and (c) Are there certain periods of time in which SL participation is more predictive of graduating within four, five, or six years?

The present study not only responded to the call for more longitudinal studies on SL and graduation, but also expanded upon the Lockeman and Pelco (2013) study in the following ways. First, this study expanded the dataset by including multiple entering undergraduate cohorts for both first-time freshmen and new undergraduate transfers. Second, this study operationalized SL participation to include both the given and the previous time periods, rather than only in the given time periods. Previous research has suggested that students' prior SL experiences are related to subsequent SL experiences (Jameson, Clayton, \& Bringle, 2008), so this cumulative view of SL participation allowed us to capture the potential influences of SL participation in the previous terms. Third, the present study focused on how the different levels of SL course participation, the timing of SL participation, and the related underlying factors may moderate or mediate students' likelihood of graduation in a particular term. Finally, the study tracked and analyzed students' SL participation and graduation term-by-term, rather than year-by year, over six years. This analysis provided a more detailed view of the dynamic relationship between students' SL participation and graduation within six years.

\section{Event History Analysis}

SL courses are usually offered in every semester and students may take them in any semester during their undergraduate years. These conditions raise challenges in evaluating SL with longitudinal data. First, the status of a student's SL participation may vary across terms because students may take SL courses in any term. Second, the effect of SL may be sensitive to when a SL course was taken; there possibly are certain time periods in which taking SL is more influential than in other periods. In a longitudinal process, we need to examine the potential time-varying effects of SL participation. Finally, it is common for certain students to drop out of school at any time permanently or temporarily, particularly in the early terms (Chen, 2012; DesJardins, Ahlburg, \& McCall, 2002; Ryan, 2004). This is related to the so-called "right-censured" data that we will discuss in detail in the next section.

To capture the temporal nature of SL participation and to accurately estimate the effects (in particular the time-varying effects) of SL on graduation, we employed EHA. With roots in biostatistics and epidemiology, EHA adopted different names across different scientific disciplines - survival analysis, duration models, hazard models, or failure-time models. EHA is an empirical technique that allows the researcher to study the occurrence and timing of events in a longitudinal process (DesJardins, 2003), 
and has been recently used in higher education research to investigate the temporal aspects of student dropout and degree completion (Chen, 2008, 2012; DesJardins et al.; Yue \& Fu, 2017). EHA focuses on events that are important to the dependent variable and analyzes data obtained by observing individuals over time. It can examine the underlying causal mechanisms behind event occurrence so as to control for censored data and to explore the impact of time-dependent variables on outcomes (Allison, 1982, 1984; Singer \& Willett, 2003).

In our study, the event of interest is graduation with a Bachelor's degree in a term within six years. If a student has not graduated at the end of an observation period, this may indicate that either the student continued enrollment, graduated elsewhere, or dropped out; thus, the time of graduation is unknown. All the cases for which graduation is unknown are right-censored, but they must be considered in estimation with longitudinal events to avoid biases or loss of information (Alison, 1984).

Right-censored data provide incomplete information; whether or when the event occurs for the censored individuals is unknown, but nonoccurrence of the event, by the censoring time, is known. EHA can handle this uncertainty by incorporating information about right-censored cases. In our study, we tracked students term by term. In each term (referred to as "risk period" in EHA terminology), we only counted students who were enrolled in that term. The pool of these students, the "risk set," includes all individuals eligible to experience the event in that term at the institution studied. Students who graduated or were censored in one term would be dropped out of the "risk set" in future time periods so that everyone remains in this set only up to the last term of enrollment.

\section{Method}

\section{Data}

The SL program under study was established in 1988 and currently offers approximately 150 SL course sections each year. All SL courses are uniquely identified in the institution's enterprise information system and designated as " $\mathrm{S}$ " sections in registration catalogs. A university academic committee reviews all SL courses. To be approved, courses must meet the following requirements: (a) the SL component is integral to and supportive of the academic focus of the course; (b) the course has a mechanism to introduce the service ethic; (c) students are required to perform at least 15 hours of academically relevant community service; (d) SL accounts for at least $15 \%$ of the total course grade; and (e) ongoing structured opportunities for critical reflection on the service experience are provided.

Data in the study included eight entering cohorts of first-time full time freshmen $(N=19,709)$ and new full time undergraduate transfers $(N=11,365)$ from Fall 2002 to Fall 2009. The observation period was six years, including six fall and six spring semesters. All students were tracked from the first term to the last enrolled term (if the student graduated or dropped out within six years), or the $12^{\text {th }}$ term (if the student did not graduate and remained in school beyond the $12^{\text {th }}$ term). The final person-period dataset included 31,074 students with 210,609 records $(N=150,948$ for first-time freshmen and $N=59,661$ for new undergraduate transfers, per student per enrolled term).

SL course characteristics. This study included 1,520 undergraduate SL courses taken by students during the observation period, covering 185 unique courses in 59 different subjects or majors. There were only three SL courses taken by students in summer sessions and these were folded into the respective previous spring semesters. The majority of SL courses were upper division (UD) courses and non-general education (non-GE) courses. Most of these non-GE courses were required major courses. The general education (GE) SL courses spanned a variety of disciplines.

Student characteristics. At entry, $40.4 \%$ of firsttime freshmen and $43.7 \%$ of new undergraduate transfers were male; $47.6 \%$ of first-time freshmen and $44.4 \%$ of new undergraduate transfers were eligible for Pell grant; $60.7 \%$ of first-time freshmen and $57.1 \%$ of new undergraduate transfers were first-generation college-going students (FGS); and $40.5 \%$ of first-time freshmen and $34.9 \%$ of new undergraduate transfers were under-represented minority students (URM) defined as African American, American Indian, and Hispanic or Pacific Islander. However, the proportions of these four characteristics increased across terms, especially in the later terms.

Among 11,365 new full time undergraduate transfers in the dataset, $4.9 \%$ were freshmen, $13.8 \%$ were sophomores, $69.3 \%$ were juniors, and $11.9 \%$ were seniors. These students had already earned 65.3 college units on average at entry.

By the end of six years, $50.5 \%(9,955$ of 19,709$)$ first-time freshmen and $73.0 \%(8,300$ of 11,365$)$ new undergraduate transfers had graduated with a Bachelor's degree. First-time freshmen mainly graduated in the late terms $\left(8^{\text {th }}\right.$ to $\left.12^{\text {th }}\right)$ while new transfers mainly graduated in the early terms $\left(4^{\text {th }}\right.$ to $8^{\text {th }}$. Evidence suggests that students who transferred to other institutions have lower degree completion rates than students who began and complet- 
ed their tenure at the same institutions (Alfonso, 2006; Davis, 2012; Dennis, Calvillo, and Gonzalez, 2008; Handel \& Williams, 2013; Laanan, 2001; Li, 2010; Monaghan \& Attewell, 2015; Peter, Cataldi, $\&$ Carroll, 2005). Credit loss, remediation enrollment, and lack of major prerequisites have been identified as mechanisms that influence transfer students' pathways to degree completion (Attewell, Heil, \& Reisel, 2012; Bailey, Jaggars, \& Jenkins, 2015; Scott-Clayton, Crosta, \& Belffield, 2014). As such, these two groups of students were analyzed separately to attempt to capture these potential influences.

\section{Variables}

We tracked students term by term for 12 terms. At the end of each term, the graduation status of a student was identified as the dependent variable: 1 if graduation occurred and 0 if graduation did not occur.

The independent variable of interest was SL participation by the end of a term, defined in the four different ways as described below.

$S L$ taking group. SL participation status with two categories: $0=$ did not take any SL courses and $1=$ took at least one SL course by the end of a term.

Lower division (LD) and upper division (UD) SL taking group. Previous SL research has identified how the type of course, such as major requirement or GE, is related to student outcomes (Roldan et al., 2004). As such, the following SL participation categories were constructed to capture these potential influences: $0=$ did not take any SL courses, 1 $=$ took lower LD SL courses only, $2=$ took UD SL courses only, and $3=$ took both LD and UD SL courses.

Total number of SL courses taken. The number of SL courses taken by the end of the given term, which is a continuous variable $(0,1,2 \ldots$ and so on).

The number of LD and UD SL courses taken. This grouping considers students' participation in both LD and UD SL courses taken by the end of term as two separate continuous variables $(0,1$, $2 \ldots$ and so on).

We also included four demographic variables (gender, URM status, FGS status, Pell eligible status) and two academic performance variables - cumulative GPA and cumulative units earned at the beginning of the term as control variables. The latter two are included because both have been found to be the most significant factors affecting students' graduation within six years (Yue \& Fu, 2017). We used high school GPA of first-time freshmen and transfer GPA of new undergraduate transfers as the cumulative GPA in the beginning of the term for the first terms.

\section{Statistical Models}

Within the class of EHA methods, we chose the discrete-time logit hazard model, which can be estimated by a standard maximum likelihood method using a logistic regression procedure. We first specify and estimate a time-fixing effect model, assuming the effects of independent variables do not change over time. This model provides the estimated overall effect of the independent variables across all time periods. However, an independent variable's effect may increase or decrease over time, in alignment with certain events occurring at specific time periods. In fact, both time-dependent and time-independent variables can have time-varying effects. To further explore the possibility of the time-varying effects of the independent variables, we then specify and estimate a time-varying effect model that allows the effects of the independent variables to differ from period to period, examining the unique effects of the independent variables in each period. The detailed model specification and reference can be found in the literature (Singer \& Willett, 2003; Yue \& Fu, 2017).

In both models, the slope parameters $(\beta \mathrm{s})$ indicate the effects of the independent variables and can be interpreted in two ways. First, it is the computed odds ratio, $\operatorname{Exp}(\beta)$, that assesses the relative probability the event of the dependent variable will occur. $\operatorname{An} \operatorname{Exp}(\beta)$ larger than 1 indicates a positive effect of the independent variable while an $\operatorname{Exp}(\beta)$ smaller than 1 indicates a negative effect. The farther the $\operatorname{Exp}(\beta)$ is from 1, the greater the effect is. For example, $\operatorname{Exp}(\beta)=1.254$ for SL taking $(1=$ took at least one SL courses and $0=$ did not take any SL courses) means the odds of graduating for students who took at least one SL course is 1.254 times of those who did not take any SL courses. Alternatively, a simple transformation of the $\beta$ 's offers a direct interpretation: $100\left(\mathrm{e}^{\beta}-1\right)$ is the percentage change in the odds of graduation for a one unit increase in $\mathrm{X}$, holding other variables constant. Therefore, $\operatorname{Exp}(\beta)=1.109$ for the total number of SL courses taken means the odds of graduating would increase $10.9 \%$ if students took one more SL course.

Considering the possible moderating influences of the factors related to faculty and course performance in the literature (Aronson et al., 2005; Roldan, Strage, \& David, 2004; Whitley, 2014), we conducted an expanded analysis including the moderating variables. The variables related to faculty members who taught SL courses were full-time status, tenured/tenure track status, and SL training 
experience. The variables related to students' performance in SL courses were course grades and course passing rate.

\section{Results}

\section{SL Participation}

Table 1 summarizes students' SL participation across terms within the observation period of six years. SL courses were offered every semester and students took SL courses at different points of time along their educational pathway. More students initially took SL courses in the early terms, particularly in the first two terms (23.0\% for first-time freshmen and $17.1 \%$ for new undergraduate transfers). After that, initial participation varied throughout the subsequent terms. Overall, we found that approximately $10 \%$ of enrolled students, including both first-time freshmen and new transfers, took SL courses in a semester, which is similar to the finding reported by Lockeman and Pelco (2013). We also found that $52.5 \%$ of first-time freshmen and $40.7 \%$ of new undergraduate transfers took at least one SL course during the six years, which is almost double what Lockeman and Pelco reported. These results indicate that SL participation rates vary across the two institutions in their study and ours.

\section{Graduation by SL Participation}

Table 2 presents the percentages of graduation across terms by SL participation status. The percentage of graduation is calculated as the number of students who graduated in a term divided by the number of students who had "survived" to (or did not graduate before that term and continuously enrolled in) that term. The differences in the percentage of graduation among SL taking subgroups indicate how SL participation was associated with students' graduation at the end of a term. A larger difference indicates a greater association. In addition, the stable differences across terms indicate that the SL participation-graduation relationship was similar across terms.

SL taking group. For both first-time freshmen and new undergraduate transfers, on average, the percentage of graduated students who participated in SL courses was statistically significantly higher than for those who did not participate in SL courses $(10.5 \%$ vs. $3.6 \%$ and $21.6 \%$ vs. $9.4 \%$, respectively). This was true for most terms starting in the $7^{\text {th }}$ term for first-time freshmen and the $3^{\text {rd }}$ term for new undergraduate transfers. However, the difference between first-time freshmen SL participants and non-participants slightly increased in the later terms. For new undergraduate transfers, the difference between SL participants and non-participants became larger after the $5^{\text {th }}$ term. There were much larger differences across terms for new undergraduate transfers than for first-time freshmen, indicating that SL had a stronger relationship with graduation for new transfers than for first-time freshmen.

$L D$ and $U D S L$ taking groups. For first-time freshmen, on average, there was a statistically significant difference between students who took LD SL courses and those who did not take any SL courses $(5.1 \%$ vs. $3.6 \%)$. However, the differences in most terms were not statistically significant. There were no statistically significant differences between first-time freshmen who took both LD and UD SL courses and those who took only UD SL courses, on average $(20.1 \%$ vs. $18.9 \%)$ or in most terms. However, there were statistically significant differences between first-time freshmen who took only UD SL (18.9\%) or a combination of UD and LD SL courses $(20.1 \%)$ and those who took only LD SL courses $(5.1 \%)$ or did not take any SL courses $(3.6 \%)$, on average and in the $6^{\text {th }}$ or later terms. These results indicate that UD SL courses had a stronger relationship with graduation for first-time freshmen.

For new undergraduate transfers, on average, there were statistically significant differences in the percentage of graduated students among all four groups. The percentages of graduated students who took a combination of LD and UD SL courses (27.2\%) and those who took only UD SL courses $(23.0 \%)$ are both much larger than the percentages of graduated students who took only LD SL courses $(12.8 \%)$ and those who did not take any SL courses $(9.4 \%)$. These results indicate that UD SL courses have a stronger relationship with graduation for new undergraduate transfers, too.

The total number of SL courses taken. On average, students who took two or more SL courses had the significantly highest percentage of students who had graduated in a term, followed by students who took only one SL course. Further, students who did not take any SL course had the significantly lowest percentage that had graduated in a term. This pattern was similar for both first-time freshmen and new undergraduate transfers. Overall, taking more SL courses had a stronger relationship with graduation across terms for both groups of first-time freshmen and new transfers.

The number of LD SL courses taken. For firsttime freshmen, on average, students who took two or more LD SL courses had the significantly highest percentage that had graduated in a term, followed by students who took only one LD SL course. Further, students who did not take any LD SL course 


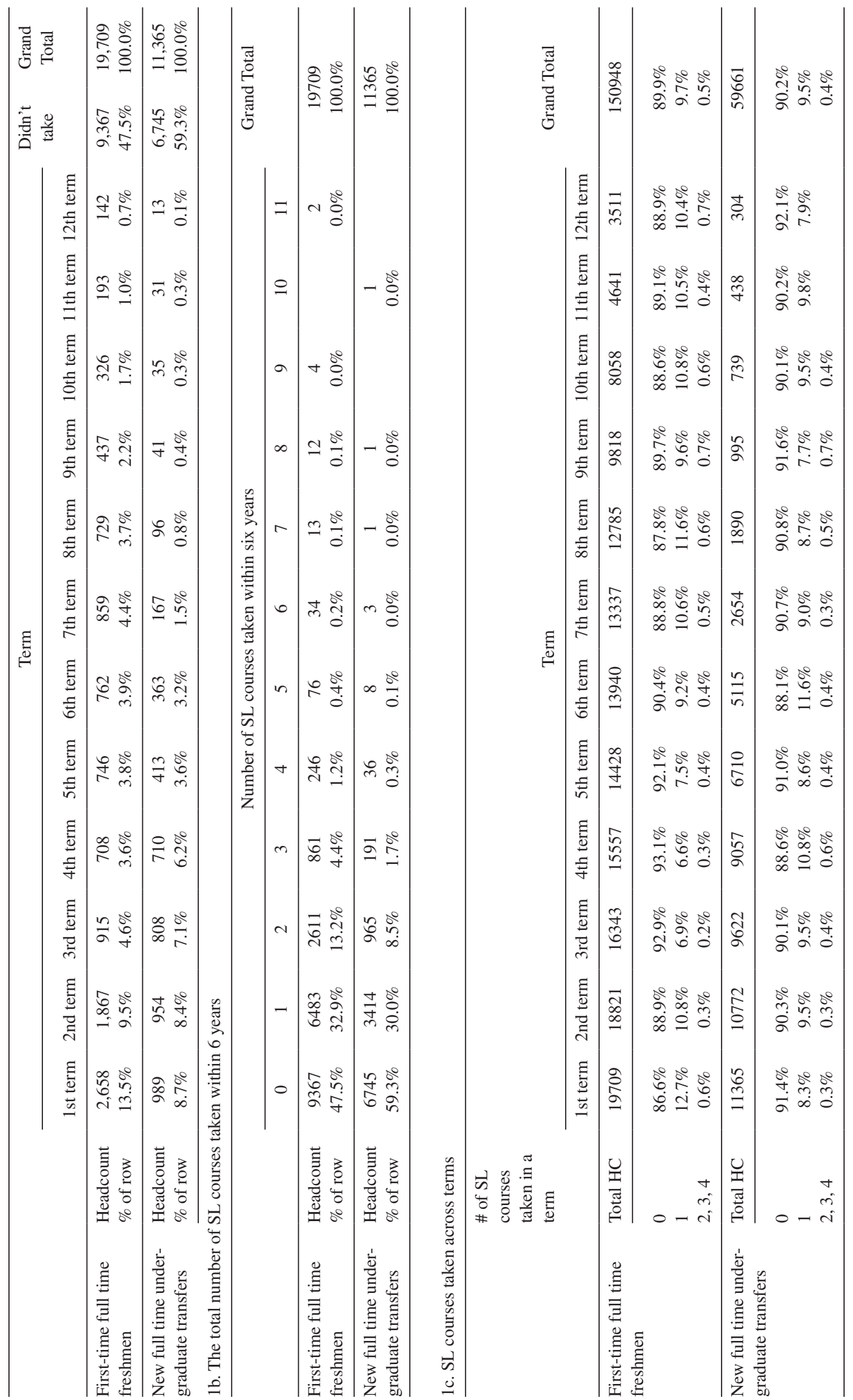




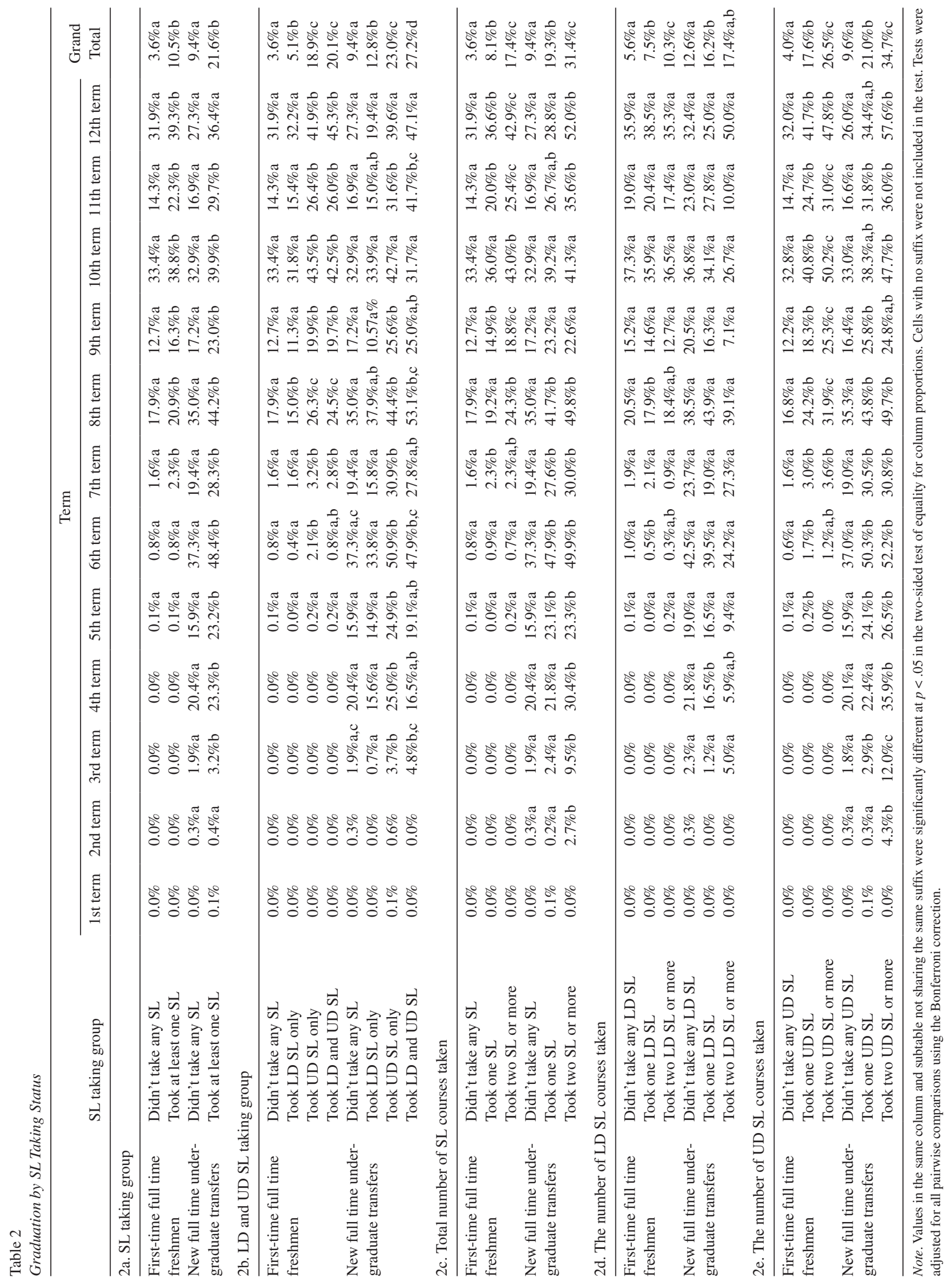


have the significantly lowest percentage of students who had graduated. However, within most of the individual terms, the differences among these three LD SL groups were not statistically significant. For new undergraduate transfer students, there are no statistically differences among the three LD SL groups, on average or in most terms.

The number of UD SL courses taken. For both first-time freshmen and new undergraduate transfers, on average, students who took two or more UD SL courses have the significantly highest percentage of students who had graduated in a term, followed by students who took only one UD SL course. Students who did not take any UD SL course have the significantly lowest percentage of graduated students. Furthermore, for both first-time freshmen and new undergraduate transfers, on average, students who took two or more UD SL courses and students who took one UD SL course had much higher percentages of graduation than students who did not take any UD SL course $(26.5 \%$ and $17.6 \%$ vs. $4.0 \%$ for first-time freshmen, $34.7 \%$ and $21.0 \%$ vs. $9.6 \%$ for new undergraduate transfers). Overall, increased participation in UD SL courses is associated with higher graduation percentages for both first-time freshman and new transfer students.

\section{Modeling the Relationship between SL Participation and Graduation}

In the following, we employed EHA, particularly the discrete-time logit hazard models to analyze the relationship between SL participation and graduation when considering four demographic variables: gender, URM status, FGS, and Pell grant eligible status. We also considered two academic performance variables at the beginning of the term $(\mathrm{Cu}-$ mulative GPA and cumulative units' earned in the beginning of terms) as the controlling variables in the models. To simplify the interpretation of statistical results, we only reported the estimated odds ratios $[\operatorname{Exp}(\beta)]$ of graduating in a term for different SL participation groups and the corresponding model R-squares (Nagelkerk's R-square) in Table 3 . The detailed statistical results from time-fixing effect models were reported in Table 4 to analyze the influences of covariates in graduation across terms within six years.

$S L$ taking group. The time-fixing effect models in the left-hand panel in Table 3 explained 53.2\% and $37.4 \%$ of the total variance in the dependent variable for first-time freshmen and new undergraduate transfers, respectively. SL participation had a significantly positive relationship with graduation for both first-time freshmen and new undergraduate transfers. Based on the estimated odds ratio of graduation and the percentage change in the odds of graduation, first-time freshmen who took at least one SL course were $25.4 \%$ more likely to graduate in the end of a term during this six-year period than who those who did not do so. Similarly, new undergraduate transfers who took at least one SL course were $59.0 \%$ more likely to graduate in the end of a term during this six-year period than those who did not do so.

$L D$ and UD SL taking group. Based on the estimated odds ratio of graduation and the percentage change in the odds of graduation in Table 3, firsttime freshmen who took only UD SL courses or a combination of LD and UD SL courses were significantly more likely to graduate than those who did not take any SL courses $(40.3 \%$ and $40.9 \%$, respectively). Similarly, new undergraduate transfers who took only UD SL courses or a combination of LD and UD SL courses were significantly more likely to graduate than those who did not take any SL courses (72.0\% and $37.7 \%$, respectively). However, for both first-time freshman and new transfer student groups there was no statistically significant difference in likelihood of graduation when comparing students who took only LD SL courses to those who did not take any SL courses.

The total number of SL courses taken. The total number of SL courses taken had a statistically significant positive relationship with graduation for both first-time freshmen and new undergraduate transfers. One additional SL course taken was associated with an increase in the likelihood of graduation by $10.9 \%$ for first-time freshmen and by $33.9 \%$ for new undergraduate transfers.

The number of LD and UD SL courses taken. Taking one additional UD SL course was significantly and positively associated with an increase in the likelihood of graduation by $21.0 \%$ for firsttime freshmen and $46.2 \%$ for new undergraduate transfers. In addition, taking one additional LD SL course was significantly associated with a decrease in the likelihood of graduation for new undergraduate transfers. There is no statistically significant relationship between the number of LD SL courses taken and the likelihood of graduation for first-time freshmen.

\section{Differential Relationships of \\ SL Participation with Graduation}

The results above suggest two differential relationships between SL participation and student graduation. First, participation in UD SL courses had a stronger positive association with graduation than participation in LD SL courses. Second, SL participation had a stronger positive association 


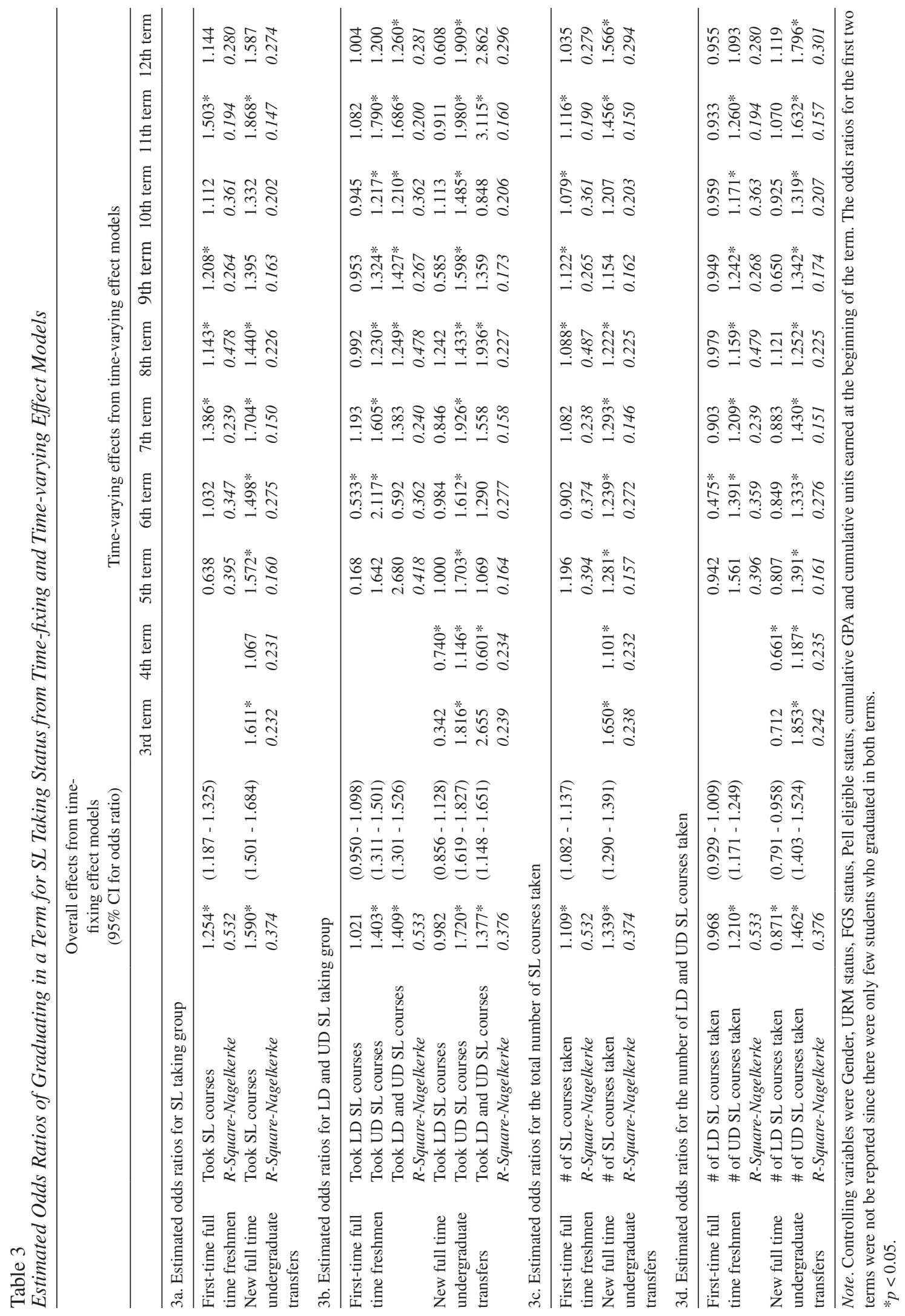


with graduation for new transfer students than first-time freshman. To determine if both differential relationships are statistically significant, 95\% confidence intervals (CIs) for the odds ratios are reported in the left-hand panel in Table 3. If two odds ratios have non-overlapping confidence intervals, they are necessarily significantly different (even through it is not necessarily true that they are not significantly different if they have overlapping confidence intervals) (Knezevic, 2008).

The $95 \%$ CI for the odds ratio of the number of UD SL courses taken was above that for the number of LD SL courses taken, without any overlap for first-time freshmen (1.171-1.249 vs. 0.929$1.009)$ or for new undergraduate transfers (1.4031.524 vs. $0.791-0.958)$. The $95 \%$ CI for the odds ratios of students who took only UD SL courses or students who took a combination of both LD and UD SL courses were above that for students who took only LD SL courses, without any overlap (1.311-1.501 or $1.301-1.526$ vs. $0.950-1.098$ for first-time freshmen and 1.619-1.827 or 1.148-1.651 vs. 0.856-1.128 for new undergraduate transfers).

Regarding the relationship of SL participation with student graduation between first-time freshmen and new transfers, the $95 \%$ CI for the odds ratio of SL participation for new undergraduate transfers was above that for first-time freshmen without any overlap, which was true in terms of both the total number of SL courses taken (1.290-1.391 vs. 1.082-1.137) and SL taking group (1.501-1.684 vs. 1.187-1.325). Thus, both differential relationships were statistically significant. More specifically, participation in UD SL courses had a statistically significant stronger positive association with graduation than participation in LD SL courses. And SL participation had a statistically significant stronger positive association with graduation for new transfer students than first-time freshman.

Further investigation indicated that both differential relationships were related to certain common factors moderating the relationships of SL participation with graduation as described in the next paragraphs. Table 4 compares the characteristics related to SL courses, faculty, and students for both LD and UD SL courses and for both first-time freshmen and new undergraduate transfers.

Significantly more UD SL courses were non-GE courses, the majority of which were also majorrelated courses, than were LD SL courses $(96.2 \%$ vs. $54.0 \%$ ). Particularly, UD SL courses taken by students were significantly closer to students' major areas. For example, $68.3 \%$ of UD SL courses taken by students were in students' major colleges, compared to $30.7 \%$ for LD SL courses. Furthermore, $40.4 \%$ of UD SL courses taken by students were in students' major departments whereas only $20.3 \%$ of LD SL courses taken were in students' major departments. The second set of factors relate to the characteristics of faculty members who taught SL courses. Significantly more UD SL courses were taught by full-time faculty members $(65.1 \%$ vs. $54.4 \%)$, tenured/tenure track faculty members $(49.1 \%$ vs. $29.6 \%)$, or faculty members who had SL training experience $(32.1 \%$ vs. $27.0 \%)$ than LD SL courses. The last set of factors in Table 4 is students' performance in SL courses. Students in UD SL courses received significantly higher course grades and course passing rates than students in LD SL courses (3.21 vs. 2.97 on a 4.0 scale for the average course grade and $94.2 \%$ vs $89.6 \%$ for the course passing rate).

As will be discussed below, these characteristics may explain why SL participation had a stronger association with graduation for new transfer students than for first-time freshman. Compared to first-time freshmen, new transfers were significantly more likely to take UD SL courses $(84.9 \%$ vs. $50.7 \%)$ and non-GE SL courses (93.4\% vs. 70.2\%). They were significantly more likely to take SL courses within their major colleges $(67.7 \%$ vs. $47.8 \%)$ and major departments (40.4\% vs. $29.4 \%$ ) and were significantly more likely to take the SL courses taught by full-time faculty members $(61.8 \%$ vs. $56.7 \%)$, tenured/tenure track faculty members $(42.3 \%$ vs. $36.0 \%$ ), or faculty members who had SL training experience (29.8\% vs. $28.0 \%)$. In addition, they also performed significantly better than first-time freshmen in SL courses in terms of course grade ( 3.18 vs. 3.08 on a 4.0 scale) and course passing rate $(93.4 \%$ vs. $91.9 \%)$.

Time-varying effects of SL taking. The timevarying effects models (in the right panels in Table 3) provide the term-specific odds ratios of graduation in a term across terms. For all four types of SL participation status, the estimated odds ratios varied across terms. However, there is no clear pattern or trend regarding in which term SL participation was more associated with graduation. In most terms, the direction and the size of the relationships were similar to the overall relationship from the timefixing effect models. That the estimated odds ratios varied across terms without any clear patterns or trends indicates that taking SL courses in a term has a significantly positive relationship with students' graduation in any sequential terms.

The influences of covariates in graduation. Table 5 provides the detailed results from time-fixing effect models for SL participation defined as the number of SL courses taken. The time-fixing effect models allow us to evaluate the overall influences of covariates on graduation across terms within six 
Table 4

Factors Moderating the Relationships of Service-learning with Graduation

4a. Comparisons between lower and upper division SL courses

\begin{tabular}{|c|c|c|c|}
\hline & & Lower division & Upper division \\
\hline \multirow[t]{2}{*}{ SL course enrollment } & Number of SL courses taken & 537 & 983 \\
\hline & Enrolled Headcount & 8,865 & 13,367 \\
\hline \multirow[t]{5}{*}{ Course characteristics } & $\%$ of Upper division SL courses & $0.0 \%$ & $100.0 \%$ \\
\hline & $\%$ of Non-GE SL courses & $54.0 \%$ & $96.2 \% * * *$ \\
\hline & $\begin{array}{l}\% \text { of Students who took SL courses in their major } \\
\text { colleges }\end{array}$ & $30.7 \%$ & $68.3 \% * * *$ \\
\hline & $\begin{array}{l}\% \text { of Students who took SL courses in their major } \\
\text { departments }\end{array}$ & $20.3 \%$ & $40.4 \% * * *$ \\
\hline & Median of Class size & 27 & $28 * *$ \\
\hline \multirow[t]{3}{*}{ Instructor characteristics } & $\%$ of SL courses taught by full-time instructors & $54.4 \%$ & $65.1 \% * * *$ \\
\hline & $\begin{array}{l}\% \text { of SL courses taught by tenured/tenure-track } \\
\text { instructors }\end{array}$ & $29.6 \%$ & $49.1 \% * * *$ \\
\hline & $\begin{array}{l}\% \text { of SL courses taught by instructors who had SL } \\
\text { training }\end{array}$ & $27.0 \%$ & $32.1 \% *$ \\
\hline \multirow[t]{2}{*}{ Student performance } & Average course grade & 2.97 & $3.21 * * *$ \\
\hline & Course passing rate & $89.6 \%$ & $94.2 \% * * *$ \\
\hline
\end{tabular}

4b. Comparisons between first-time freshmen and new undergraduate transfers

\begin{tabular}{|c|c|c|c|}
\hline & & $\begin{array}{l}\text { First-time full } \\
\text { time freshmen }\end{array}$ & $\begin{array}{c}\text { New full time } \\
\text { undergraduate } \\
\text { transfers }\end{array}$ \\
\hline \multirow[t]{2}{*}{ SL course enrollment } & Number of SL courses taken & 1,370 & 1,099 \\
\hline & Enrolled Headcount & 16,089 & 6,143 \\
\hline \multirow[t]{5}{*}{ Course characteristics } & $\%$ of Students who took Upper division SL courses & $50.7 \%$ & $84.9 \% * * *$ \\
\hline & $\%$ of Students who took Non-GE SL courses & $70.2 \%$ & $93.4 \% * * *$ \\
\hline & $\begin{array}{l}\% \text { of Students who took SL courses in their major } \\
\text { colleges }\end{array}$ & $47.8 \%$ & $67.7 \% * * *$ \\
\hline & $\begin{array}{l}\% \text { of Students who took SL courses in their major } \\
\text { departments }\end{array}$ & $29.4 \%$ & $40 . \% * * *$ \\
\hline & Median of Class size & 28 & 28 \\
\hline \multirow[t]{3}{*}{ Instructor characteristics } & $\begin{array}{l}\% \text { of Students who took SL courses taught by full-time } \\
\text { instructors }\end{array}$ & $56.7 \%$ & $61.8 \% * * *$ \\
\hline & $\begin{array}{l}\% \text { of Students who took SL courses taught by tenured/ } \\
\text { tenure-track instructors }\end{array}$ & $36.0 \%$ & $42.3 \% * * *$ \\
\hline & $\begin{array}{l}\% \text { of Students who took SL courses taught by } \\
\text { instructors who had SL training }\end{array}$ & $28.0 \%$ & $29.8 \% *$ \\
\hline \multirow[t]{2}{*}{ Student performance } & Average course grade & 3.08 & $3.18 * * *$ \\
\hline & Course passing rate & $91.9 \%$ & $93.4 \% * * *$ \\
\hline
\end{tabular}

Note. $* p<0.05, * * p<0.01, * * * p<0.001$. Independent samples t-tests were used to test the mean difference in course grade, independent samples Median Tests were used for the difference in medians of class size, and Pearson Chi-Square tests were used for the categorical variables.

years. The choices of time-fixing effect models and SL participation defined as the number of SL courses taken was for comparison purposes because both are closer to Lockeman and Pelco (2013).

Among seven variables in the models, the most significant variables were two academic performance measures (cumulative GPA and cumulative units earned in the beginning of terms), followed by the number of SL courses taken and gender, and then Pell eligible status and FGS status in terms of their statistical significances (Wald statistics). Firsttime freshman students were more likely to graduate within six years if they had higher cumulative GPA and earned more units, took more SL courses, were female, were not eligible for Pell grants, and were first-generation students. These characteristics hold for the new transfer students as well, except that the difference between first-generation students and students who were not first-generation was not statistically significant. In addition, our model found that URM status was not a significant factor related to students' graduation within six years.

The significantly positive association of SL participation with graduation found in this study is consistent with the finding of Lockeman and Pelco (2013), even though we defined SL participation 
Table 5

Detailed Results from Time-fixing Effect Models

\begin{tabular}{|c|c|c|c|c|c|c|}
\hline Variable & $\beta$ & S.E. & Wald & df & Sig. & $\operatorname{Exp}(\beta)$ \\
\hline \multicolumn{7}{|l|}{ 5a. First-time full time freshmen } \\
\hline \# of SL courses taken & 0.103 & 0.013 & 66.320 & 1 & 0.000 & 1.109 \\
\hline Gender (Female compared to Male) & 0.224 & 0.028 & 61.957 & 1 & 0.000 & 1.251 \\
\hline URM (compared to Non-URM) & -0.045 & 0.030 & 2.300 & 1 & 0.129 & 0.956 \\
\hline FGS (compared to Non-FGS) & 0.079 & 0.031 & 6.688 & 1 & 0.010 & 1.082 \\
\hline Pell eligible (compared to Non-eligible) & -0.190 & 0.031 & 38.592 & 1 & 0.000 & 0.827 \\
\hline Cumulative GPA in the beginning of term & 0.290 & 0.029 & 102.418 & 1 & 0.000 & 1.336 \\
\hline Cumulative units earned in the beginning of term & 0.072 & 0.001 & 11139.850 & 1 & 0.000 & 1.075 \\
\hline Constant & -10.917 & 0.118 & 8554.300 & 1 & 0.000 & 0.000 \\
\hline \multicolumn{7}{|l|}{ 5b. New full time undergraduate transfers } \\
\hline \# of SL courses taken & 0.292 & 0.019 & 229.167 & 1 & 0.000 & 1.339 \\
\hline Gender (Female compared to Male) & 0.243 & 0.030 & 66.139 & 1 & 0.000 & 1.275 \\
\hline URM (compared to Non-URM) & -0.021 & 0.032 & 0.437 & 1 & 0.509 & 0.979 \\
\hline FGS (compared to Non-FGS) & 0.041 & 0.031 & 1.788 & 1 & 0.181 & 1.042 \\
\hline Pell eligible (compared to Non-eligible) & -0.243 & 0.031 & 62.113 & 1 & 0.000 & 0.784 \\
\hline Cumulative GPA in the beginning of term & 0.746 & 0.033 & 508.244 & 1 & 0.000 & 2.109 \\
\hline Cumulative units earned in the beginning of term & 0.054 & 0.001 & 7290.246 & 1 & 0.000 & 1.056 \\
\hline Constant & -10.650 & 0.139 & 5906.454 & 1 & 0.000 & 0.000 \\
\hline
\end{tabular}

differently (number of SL courses taken vs. number of SL credits earned). On the other hand, Lockeman and Pelco found that gender, race/ethnicity, financial need, financial aid, and number of semesters with Pell support were not significant factors affecting student graduation.

\section{Discussion}

This study examined how participation in SL courses was related to the graduation of first-time freshman and new transfer students. The overall findings of this study provided evidence that participation in SL courses increased students' likelihood of earning a baccalaureate degree. Moreover, participation in multiple SL courses was associated with an even higher likelihood of degree attainment. Similar to previous research, individual student characteristics, such as cumulative GPA and units earned, gender, and social-economic status, were factors associated with student graduation within six years (Astin \& Oseguera, 2005; Crisp \& Nora, 2010; DeAngelo et al., 2011; Pike et al., 2014). However, similar to Lockeman and Pelco (2013), controlling for these factors found that SL participation had a significantly positive association with graduation within six years for first-time freshman. In addition, the current study found a significantly positive association with graduation for new transfer students. The present study also found some unique relationships between SL participation and student graduation. First, participation in multiple SL courses had a stronger association than partic- ipation in one SL course. Second, participation in UD SL courses had a significantly stronger association with graduation than participation in LD SL courses. Third, SL participation had a significantly stronger association with graduation for new transfer students than first-time freshman.

We propose that the SL-graduation relationship is associated with the ways that SL creates engaging and relevant learning experiences, which promote students' commitment to their educational pursuits. Kuh and his colleagues (Kuh et al., 2005) proposed that increasing student engagement as well as deeper levels of cognitive and behavioral participation enhance students' levels of learning and likelihood of success in college. Research suggests that SL provides the conditions to promote such engagement, particularly through structures that involve autonomy and ownership of the learning process, application of course content in authentic settings, and reflection on personal development (Eyler \& Giles, 1999; Hart \& King, 2007; Pak, 2016; Yeh, 2010). Moreover, previous research on student retention has found that SL participation increases students' likelihood of continuing enrollment and maintaining an intention to persist toward degree completion (Bringle et al., 2010; Gallini \& Moely, 2003). These studies specifically identified that the academic challenge and engagement fostered through SL pedagogy are keys to facilitating student persistence. As such, SL can be viewed as a pedagogy of engagement that fosters students' pursuit of immediate academic goals and long-term aspira- 
tions. Further, the current results support previous research that found students' prior SL experiences influence subsequent SL experiences (Jameson et al., 2008). Indeed, multiple experiences with SL courses has a cumulative effect on students' likelihood of graduation (Lockeman \& Pelco, 2013).

Interestingly, the present study found this SLgraduation relationship to be significantly stronger for transfer students than for first-time freshman. A substantial body of research has shown that undergraduate students who transfer to a four-year university are less likely to complete baccalaureate degrees within six years than students who persist at the same institution for their academic tenure (Davis, 2012; Dennis et al., 2008; Laanan, 2001; $\mathrm{Li}, 2010)$. These studies found that due to academic and social adjustments transfer students struggle to develop a sense of commitment to the institution and to degree completion. Tinto (1993) and Astin (1999) assert that developing such feelings of connectedness, value, and belonging are essential for students to feel satisfaction with the higher education experience and subsequently develop a commitment to graduation. Previous research has found that SL courses foster students' sense of belonging through multiple and frequent interactions with peers, faculty, and community members (Greenberg, 1997; Keup, 2005; Wolff \& Tinney, 2006). The findings of the current study suggest that the interactive and collaborative nature of SL courses create experiences that support transfer students' integration into the social and academic communities of their new institutions.

Another explanation for the SL-graduation relationship difference between transfer students and first-time freshman appears to be related to the SLgraduation relationship difference between UD and LD SL courses. Participation in UD SL courses had a significantly stronger association with graduation than participation in LD SL courses. Further analysis suggests these findings were associated with previously identified moderating factors (Table 4). In the present study, UD SL courses were more aligned with students' majors, and transfer students were more likely to take UD SL courses than first-time freshman. Research has found that student outcomes are influenced by the different types of SL courses. In particular, students tend to be more intrinsically motivated to spend more time and effort in courses related to their major areas of study (Roldan et al., 2004; Strage et al., 2002). Thus, taking SL courses associated with their majors may have increased transfer students' intrinsic motivation to engage in academic tasks, which is an academic disposition highly correlated with student persistence and degree attainment (Dennis, Phin- ney, \& Chuateco, 2005; Guiffrida 2006; Robbins, Lauver, Le, Davis, \& Langley, 2004).

UD SL courses were also more likely to be taught by full-time faculty and faculty trained in SL practices. As previous research has indicated, the quality of the SL course greatly influences student outcomes (Aronson et al., 2005; Bringle et al., 2010; Jameson et al., 2008). Full-time faculty may be more likely to have established relationships with community partners and to structure courses in ways that better prepare students prior to engaging in the SL experience. Such prior preparation has been associated with more positive outcomes (Aronson et al., 2005). Likewise, SL courses designed by faculty with expertise in SL pedagogy are more likely to include practices that strengthen SL outcomes, such as consistent support and feedback (Ash \& Clayton, 2009) and continuous critical reflection opportunities (Eyler \& Giles, 1999; Jameson et al., 2008).

Lastly, students' performance in SL courses in this study may have moderated the relationships of SL participation with graduation. Students taking UD SL courses had higher course grades and passing rates than students taking LD SL courses; transfer students had higher SL course grades and passing rates than first-time freshman. As Lockeman and Pelco (2013) found, passing a greater number of SL classes increased students' odds of graduating. We propose that these three factors - alignment of SL courses with students' areas of study, faculty expertise in SL pedagogy and practice, and student performance in SL courses moderated the SL participation-graduation relationship.

\section{Conclusions and Implications}

The results of this study suggest that SL is a high-impact practice that increased the likelihood of student graduation. Higher education institutions may want to develop SL initiatives to support efforts to increase graduation rates. Though previous research has found that students benefit from SL earlier in their academic experiences (Bringle et al., 2010; Roldan et al., 2004), the unique relationship of UD SL courses with graduation in this study suggests that institutions should develop initiatives that promote student participation in SL courses across their academic experiences. Providing LD SL courses may be beneficial to students entering the university immediately after high school; however, developing UD SL courses may benefit both the native students advancing in their academic pursuits and transfer students as they adjust to new social and academic communities. The unique UD SL course relationship with graduation also sug- 
gests that institutions should consider promoting SL course development across disciplines. Such initiatives should address the professional development of faculty, so they can design high-quality SL courses, and advisors, so they can guide students toward SL courses aligned within their majors.

The results of this study and the proposed recommendations for institutions must be considered within the limitations of this study, which we identify here and then propose directions for future research. This study was conducted at a large state university in the western U.S., in which the general characteristics and the specific SL program may be very different from other institutions. As evident by the large number of SL courses and the high percentage of students participating in these courses, this university demonstrates a strong commitment to SL program development. The university's Center for Community Engagement and ServiceLearning provides online modules for students and faculty about SL principles, goals, and practices; provides professional development institutes; supports ongoing SL faculty learning communities; and facilitates university-community partnerships. Replicating this form of analysis across different institutions could uncover other SL participationgraduation relationships or confirm those in the present research. Though we tried to identify the time-varying relationship of SL participation with graduation, we were not able to determine a clear pattern. The time-varying effects may not relate to SL participation in general but rather to participation in specific SL courses. It might be productive to analyze if SL participation in particular courses, in specific terms, is more important for students who are in specific majors than in other majors. Further, this study did not control for self-selection - whether students voluntarily chose to take a SL course or if it was a requirement. Without accounting for this factor, an estimate of the relationship of SL participation and graduation would be biased. This may lead to overestimation; students may be more motivated to select SL courses, which may influence their persistence to succeed. Thus, our analysis may suffer from self-selection bias and needs to be addressed in future research by accounting for students' reasons for course selection. Many institutions, including the one in this study, are implementing multiple high-impact practices to support student persistence and degree completion. Participating in one or more high-impact practices increases the likelihood of graduation (Finley \& McNair, 2013); therefore, future research should account for students' participation in combinations of HIPs. Lastly, we suggest that researchers employ mixed-methods, integrating qualitative ap- proaches, to provide a rich description of students' experiences, perceptions, and behaviors specific to particular SL courses. Moely, Furco, and Reed (2008) note that since SL is enacted across a range of disciplines and course types, there is a variance in the quality of courses and subsequent impacts. Qualitative approaches would extend knowledge by probing more deeply into the conditions of SL experiences, such as the type of service, location, duration, and nuanced procedures that foster students' pursuit of their academic goals.

\section{Note}

We would like to thank all reviewers for their thoughtful comments and suggestions, which helped us to improve the quality of the manuscript.

\section{References}

Alfonso, M. (2006). The impact of community college attendance on baccalaureate attainment. Research in Higher Education, 47, 837-903.

Allison, P. D. (1982). Discrete-time methods for the analysis of event histories. Sociological Methodology, 13(1), 61-98.

Allison, P. D. (1984). Event history analysis: Regression for longitudinal event data. Sage University Papers: Quantitative Applications in the Social Sciences, 07046. Newbury Park, CA: Sage.

Aronson, K. R., Webster, N. S., Reason, R., Ingram, P., Nolan, J., Mitchell, K., \& Reed, D. (2005). Using randomized control field trials in service learning research. In S. Root, J. Callahan, \& S. H. Billig (Eds.), Improving service-learning practice: Research on models to enhance impacts (pp. 141-165). Greenwich, CT: Information Age.

Ash, S.L., \& Clayton, P.H. (2009). Generating, deepening, and documenting learning: The power of critical reflection in applied learning. Journal of Applied Learning in Higher Education, 1(1), 25-48.

Astin, A. W. (1999). Student involvement: A developmental theory for higher education. Journal of College Student Development, 40, 518-529.

Astin, A. W., \& Oseguera, L. (2005). Pre-college and institutional influences on degree attainment. In A. Seidman (Ed.), College student retention: Formula for student success (pp. 245-276). Westport, CT: American Council on Education/ Praeger.

Astin, A. W., \& Sax, L. J. (1998). How undergraduates are affected by service participation. The Journal of College Student Development, 39, 251-263.

Attewell, P., Heil, S., \& Reisel, L. (2012). What is academic momentum? And does it matter? Educational Evaluation and Policy Analysis, 34(1), 27-44.

Bailey, T. R., Jaggars, S. S., \& Jenkins, D. (2015). Redesigning America's community colleges. Cambridge, MA: Harvard University Press. 
Bound, J., Lovenheim, M. F., \& Turner, S. (2012). Increasing time to baccalaureate degree in the United States. Education, 7, 375-424.

Bringle, R. G., Hatcher, J. A., \& Muthiah, R. N. (2010). The role of service-learning on the retention of firstyear students to second year. Michigan Journal of Community Service Learning, 16(2), 38-49.

Brownell, J. E., \& Swaner, L. E. (2010). Five high-impact practices: Research on learning outcomes, completion and quality. Washington, DC: Association of American Colleges and Universities.

Cataldi, E. F., Green, C., Henke, R., Lew, T., Woo, J., Shepherd, B., \& Siegel, P. (2011). 2008-09 Baccalaureate and beyond Longitudinal Study (B\&B: 08/09). First Look. NCES 2011-236. National Center for Education Statistics.

Celio, C. I., Durlak, J., \& Dymnicki, A. (2011). A metaanalysis of the impact of service-learning on students. Journal of Experiential Education, 34(2), 164181.

Chen, R. (2008). Financial aid and student dropout in higher education: A heterogeneous research approach. In J. Smart (Ed.), Higher education: Handbook of theory and research. XXIII: 209-240. New York: Springer.

Chen, R. (2012). Institutional characteristics and college student dropout risks: A multilevel event history analysis. Research in Higher Education, 53, 487-505.

Chupp, M. G., \& Joseph, M. L. (2010). Getting the most out of service learning: Maximizing student, university and community impact. Journal of Community Practice, 18, 190-212.

Clayton, P. H., Bringle, R. G., \& Hatcher, J. A. (Eds.) (2013). Research on service learning: Conceptual frameworks and assessments. IUPUI series on service learning research (Vol. 2A). Sterling, VA: Stylus Publishing.

Crisp, G., \& Nora, A. (2010). Hispanic student success: Factors influencing the persistence and transfer decisions of Latino community college students enrolled in developmental education. Research in Higher Education, 51, 175-194.

Davis, J. (2012). The first-generation student experience: Implications for campus practice, and strategies for improving persistence and success. Sterling, VA: Stylus Publishing.

DeAngelo, L., Franke, R., Hurtado, S., Pryor, J. H., \& Tran, S. (2011). Completing college: Assessing graduation rates at four-year institutions. Los Angeles: UCLA Higher Education Research Institute.

Dennis, J.M., Calvillo, E., \& Gonzalez, A. (2008). The role of psychosocial variables in understanding the achievement of transfer students at an ethnically diverse urban university. Journal of College Student Development, 49, 535-550.

Dennis, J. M., Phinney, J. S., \& Chuateco, L. I. (2005). The role of motivation, parental support, and peer support in the academic success of ethnic minority first-generation college students. Journal of College Student Development, 46, 223-236.
DesJardins, S. L. (2003). Event history methods: Conceptual issues and an application to student departure from college. In J. Smart (Ed.), Higher education: Handbook of theory and research (Vol. XVIII; pp. 421-471). New York: Agathon Press.

DesJardins, S. L., Ahlburg, D. A., \& McCall, B. P. (2002). A temporal investigation of factors related to timely degree completion. Journal of Higher Education, 73, 555-581.

Engle, J., \& Lynch, M. (2009). Charting a necessary path: The baseline report of Public Higher Education Systems in the Access to Success Initiative. Washington, DC: Education Trust.

Eyler, J. S. (2000). What do we most need to know about the impact of service-learning on student learning? Michigan Journal of Community Service Learning, 7, 11-17.

Eyler, J., \& Giles Jr, D. E. (1999). Where's the learning in service-learning? San Francisco: Jossey-Bass.

Eyler, J., Giles Jr, D. E., Stenson, C. M., \& Gray, C. J. (2001). At a glance: What we know about the effects of service-learning on college students, faculty, institutions and communities, 1993-2000. Washington, DC: Learn and Serve America National Service Learning Clearinghouse. Retrieved from http://servicelearning. org.

Finley, A. P., \& McNair, T. (2013). Assessing underserved students' engagement in high-impact practices. Washington, DC: Association of American Colleges and Universities.

Furco, A. (1996). Service-learning: A balanced approach to experiential education. Service Learning, General. Paper 128. Retrieved from http://digitalcommons.unomaha.edu/slceslgen/128

Gallini, S. M., \& Moely, B. E. (2003). Service-learning and engagement, academic challenge, and retention. Michigan Journal of Community Service Learning, 10(1), 5-14.

Greenberg, J. (1997). Service-learning in health education. Journal of Health Education, 28, 345- 349.

Guiffrida, D. A. (2006). Toward a cultural advancement of Tinto's theory. The Review of Higher Education, 29, 451-472.

Handel, S., \& Williams, R. (2013). The promise of the transfer pathway: Opportunity and challenge for community college students seeking the baccalaureate degree. New York: The College Board.

Hart, S. M., \& King, J. R. (2007). Service-learning and literacy tutoring: Academic impact on pre-service teachers. Teaching and Teacher Education: An International Journal of Research and Studies, 23, 323-338.

Jacoby, B. (2009). Civic engagement in today's higher education: An overview. In B. Jacoby \& Associates (Eds.), Civic engagement in higher education: Concepts and practices (pp. 5-30). San Francisco: JosseyBass.

Jameson, J. K., Clayton, P. H., \& Bringle, R. G. (2008). Investigating student learning within and across linked service-learning courses. In M. A. Bowdon, S. H. Billig, \& B. A. Holland (Eds.), Advances in service- 
learning research: Scholarship for sustaining servicelearning and civic engagement (pp. 3-27). Greenwich, CT: Information Age Publishing.

Kena, G., Musu-Gillette, L., Robinson, J., Wang, X., Rathbun, A., Zhang, J., . . . \& Velez, E. D. V. (2015). The condition of education 2015. NCES 2015144. National Center for Education Statistics, Washington, DC.

Keup, J. R. (2005). The impact of curricular interventions on intended second year enrollment. Journal of College Student Retention, 7(1-2), 61-89.

Knezevic, A. (2008). Overlapping confidence intervals and statistical significance. StatNews: Cornell University Statistical Consulting Unit, 73(1). Retrieved from https://www.cscu.cornell.edu/news/statnews/stnews73.pdf

Kuh, G. D. (2008). Excerpt from high-impact educational practices: What they are, who has access to them, and why they matter. Washington, DC: Association of American Colleges and Universities.

Kuh, G. D., Kinzie, J., Schuh, J. H., Whitt, E. J., \& Associates (2005). Student success in college: Creating conditions that matter. San Francisco: Jossey-Bass.

Laanan, F. S. (2001). Transfer student adjustment. New Directions for Community Colleges, 114, 5-13.

Li, D. (2010). They need help: Transfer student from four-year to four-year institutions. The Review of Higher Education, 33(2), 207-238.

Lockeman, K. S., \& Pelco, L. E. (2013). The relationship between service-learning and degree completion. Michigan Journal of Community Service Learning, 20(1), 18-30.

Lynch, M., \& Engle, J. (2010a). Big gaps, small gaps: Some colleges and universities do better than others in graduating African-American students. Washington, DC: The Education Trust. Retrieved from http://sparkaction.org/resources/38260

Lynch, M., \& Engle, J. (2010b). Big gaps, small gaps: Some colleges and universities do better than others in graduating Hispanic students. Washington, DC: The Education Trust. Retrieved from http://sparkaction. org/resources/38261

Matthews, P. H., Dorfman, J. H., \& Wu, X. (2015). The impacts of undergraduate service-learning on postgraduation employment outcomes. The International Journal of Research on Service-Learning and Community Engagement, 3(1), 1-16.

Moely, B.E., Furco, A., \& Reed, J. (20 08). Charity and social change: The impact of individual preferences on service-learning outcomes. Michigan Journal of Community Service Learning, 15(1), 37-48.

Monaghan, D. B., \& Attewell, P. (2015). The community college route to the bachelor's degree. Educational Evaluation and Policy Analysis, 37(1), 70-91.

National Conference of State Legislatures (2015). Performance-based funding for higher education. Retrieved from http://www.ncsl.org/research/education/ performance-funding.aspx

Nguyen, M., Bibo, E. W., \& Engle, J. (2012a). Advancing to completion: Increasing degree attainment by im- proving graduation rates and closing gaps for AfricanAmerican students. Washington, DC: The Education Trust. Retrieved from http://edtrust.org/wp-content/ uploads/2013/10/Advancing_AfAm.pdf

Nguyen, M., Bibo, E. W., \& Engle, J. (2012b). Advancing to completion: Increasing degree attainment by improving graduation rates and closing gaps for Hispanic students. Washington, DC: The Education Trust. Retrieved from https://edtrust.org/wp-content/ uploads/2013/10/Advancing_Hisp.pdf

Novak, J. M., Markey, V., \& Allen, M. (2007). Evaluating cognitive outcomes of service learning in higher education: A meta-analysis. Communication Research Reports, 24(2), 149-157.

Pak, C. S. (2016). Linking service-learning with sense of belonging: A culturally relevant pedagogy for heritage students of Spanish. Journal of Hispanic Higher Education. Advance Online Publication. doi: $10.1177 / 1538192716630028$

Peter, K., Cataldi, E. F., \& Carroll, C.D. (2005). The road less traveled? Students who enroll in multiple institutions. Washington, DC: National Center for education Statistics, U.S. Department of Education.

Pike, G. R., Hansen, M. J., \& Childress, J. E. (2014). The influence of students' pre-college characteristics, high school experiences, college expectations, and initial enrollment characteristics on degree attainment. Journal of College Student Retention: Research, Theory \& Practice, 16(1), 1-23.

Robbins, S. R., Lauver, K., Le, H., Davis, D., \& Langley, R. (2004). Do psychosocial and study skill factors predict college outcomes? A meta-analysis. Psychological Bulletin, 130(2), 261-288.

Roldan, M., Strage, A., \& David, D. (2004). A framework for assessing academic service-learning across disciplines. In M. Welch \& S. H. Billig (Eds.), New perspectives in service-learning: Research to advance the field (pp. 39-59). Greenwich, CT: Information Age Publishing.

Ryan, J. F. (2004). The relationship between institutional expenditures and degree attainment at baccalaureate colleges. Research in Higher Education, 45(2), 97-114.

Scott-Clayton, J., Crosta, P. M., \& Belfield, C. R. (2014). Improving the targeting of treatment: Evidence from college remediation. Educational Evaluation and Policy Analysis, 36, 371-393.

Singer, J. D., \& Willett, J. B. (2003). Applied longitudinal data analysis: Modeling change and occurrence. New York: Oxford University Press.

Strage, A., Baba, Y., Millner, S., Scharberg, M., Walker, E., Williamson, R., \& Yoder, M. (2002). What every college professor should know: Student activities and beliefs associated with academic success. Journal of College Student Development, 43, 246-266.

Tinto, V. (1993). Leaving college: Rethinking the causes and cures of student attrition (2nd ed.). Chicago: University of Chicago Press.

Warren, J. L. (2012). Does service-learning increase student learning?: A meta-analysis. Michigan Journal of Community Service Learning, 18(2), 56-61. 
Whitley, M. A. (2014). A draft conceptual framework of relevant theories to inform future rigorous research on student service-learning outcomes. Michigan Journal of Community Service Learning, 20(2), 19-41.

Wolff, M. K., \& Tinney, S. M. (2006). Service learning and college student success. The Academic Exchange Quarterly, 10(1), 57-61.

Yeh, T. (2010). Service-learning and persistence of lowincome, first-generation college students: An exploratory study. Michigan Journal of Community Service Learning, 16(2), 50-65.

Yorio, P. L., \& Ye, F. (2012). A meta-analysis on the effects of service-learning on the social, personal, and cognitive outcomes of learning. Academy of Management Learning \& Education, 11(1), 9-27.

Yue, H., \& Fu, X. (2017). Rethinking graduation and time to degree: A fresh perspective. Research in Higher Education, 58, 184-213.

\section{Authors}

HONGTAO YUE (hoyue@csufresno.edu) is a senior research analyst at the office of Institutional Effectiveness, California State University, Fresno and has been working in the field of Institutional Research (IR) for ten years. He is experienced in data processing and analyzing for assessment and research in supporting decision-making on campus. His works have been presented at national and regional IR conferences as well as published in academic journals. His current research interest is to study the time-varying effects of time-independent and time-dependent variables in higher education for advising students "doing the right thing at the right time."

STEVEN HART (smhart@csufresno.edu) is associate professor in the Literacy, Early, Bilingual and Special Education Department at California State University, Fresno. He is coordinator of the Urban Civic Education Minor program, and he teaches courses on literacy foundations, literacy assessment, and service-learning pedagogy. 